\title{
A novel paleo-bleaching proxy using boron isotopes and high-resolution laser ablation to reconstruct coral bleaching events
}

\author{
G. Dishon ${ }^{1}$, J. Fisch ${ }^{2}$, I. Horn ${ }^{3}$, K. Kaczmarek ${ }^{4}$, J. Bijma ${ }^{4}$, D. F. Gruber ${ }^{5}$, O. Nir ${ }^{1}$, Y. Popovich ${ }^{1}$, and D. Tchernov ${ }^{1}$ \\ ${ }^{1}$ The Leon H. Charney School of Marine Sciences, University of Haifa, Mount Carmel, Haifa 31905, Israel \\ ${ }^{2}$ Rosenstiel School for Marine and Atmospheric Sciences, University of Miami, 4600 Rickenbacker Causeway, \\ Miami, Florida 33149, USA \\ ${ }^{3}$ Leibniz-University of Hanover, Institute for Mineralogy, Callinstr. 3, 30167 Hanover, Germany \\ ${ }^{4}$ Alfred Wegner Institute Helmholtz center for Polar and Marine Research, Am Handelshafen 12, \\ 27570 Bremerhaven, Germany \\ ${ }^{5}$ Department of Natural Sciences, City University of New York, Baruch College, P.O. Box A-0506, 17 Lexington Avenue, \\ New York, New York 10010, USA
}

Correspondence to: D. Tchernov (dtchernov@univ.haifa.ac.il)

Received: 4 April 2015 - Published in Biogeosciences Discuss.: 1 June 2015

Revised: 7 September 2015 - Accepted: 16 September 2015 - Published: 8 October 2015

\begin{abstract}
Coral reefs occupy only $\sim 0.1$ percent of the ocean's habitat, but are the most biologically diverse marine ecosystem. In recent decades, coral reefs have experienced a significant global decline due to a variety of causes, one of the major causes being widespread coral bleaching events. During bleaching, the coral expels its symbiotic algae, thereby losing its main source of nutrition generally obtained through photosynthesis. While recent coral bleaching events have been extensively investigated, there is no scientific data on historical coral bleaching prior to 1979. In this study, we employ high-resolution femtosecond Laser Ablation Multiple Collector Inductively Coupled Plasma Mass Spectrometry (LA-MC-ICP-MS) to demonstrate a distinct biologically induced decline of boron (B) isotopic composition $\left(\delta^{11} \mathrm{~B}\right)$ as a result of coral bleaching. These findings and methodology offer a new use for a previously developed isotopic proxy to reconstruct paleo-coral bleaching events. Based on a literature review of published $\delta^{11} \mathrm{~B}$ data and our recorded vital effect of coral bleaching on the $\delta^{11} \mathrm{~B}$ signal, we also describe at least two possible coral bleaching events since the Last Glacial Maximum. The implementation of this bleaching proxy holds the potential of identifying occurrences of coral bleaching throughout the geological record. A deeper temporal view of coral bleaching will enable sci-
\end{abstract}

entists to determine if it occurred in the past during times of environmental change and what outcome it may have had on coral population structure. Understanding the frequency of bleaching events is also critical for determining the relationship between natural and anthropogenic causes of these events.

\section{Introduction}

\subsection{Coral bleaching}

Coral bleaching occurs when environmental stress, primarily increased water temperature and high irradiance (but also decreased temperature, decreased salinity and pathogenic infections), induces breakdown of the coral-algae symbiosis and the host initiates algae expulsion (Brown, 1997). As a result, corals either temporarily lose their pigmentation or die from a lack of nourishment from the algae. Bleaching is, therefore, considered an acute risk to the health of coral reefs, although some studies suggest it is an adaptive response to environmental change (Fautin and Buddemeier, 2004).

Coral bleaching was first reported in the early 20th century (Yonge et al., 1931) and heavily documented since 1979, as widespread bleaching events have been recorded with in- 
creased frequency and severity (Hoegh-Guldberg, 1999). By correlating isotopic dating of massive corals and concomitant sea surface temperatures (SSTs), it was speculated that coral bleaching may have already caused mortality events by the end of the 19th century (Yu et al., 2006). While bleaching events have been proposed to occur throughout the geological record (suggested for symbiotic foraminifera during unstable SST in the upper Eocene, Wade et al., 2008), there has been no experimentally established proxy to examine suspected paleo-coral bleaching.

\subsection{Paleo bleaching proxy}

Previous attempts at establishing a paleo-proxy for coral bleaching focused on carbon and oxygen isotopes (Heikoop et al., 2000; Suzuki et al., 2003) as well as skeletal ultraviolet fluorescence (Suzuki et al., 2003). However the balance between kinetic and metabolic processes, affected by factors such as coral growth rate and local light environment (i.e. shaded vs. unshaded side of a colony), complicates the use of these proxies (Suzuki et al., 2003). A correction method, suggested by Heikoop et al. (2000) to differentiate kinetic from metabolic effects, was recently refuted for the case of coral bleaching (Schoepf et al., 2014a). Boron isotopes, currently used for estimating $\mathrm{pH}_{\mathrm{sw}}$, may act as an effective paleobleaching proxy, as kinetic effects apparently do not interfere with isotopic equilibrium during calcification (Zeebe et al., 2001).

Considerable research has been focused on paleotechniques for estimating $\mathrm{pH}_{\mathrm{sw}}$ and $p \mathrm{CO}_{2 \text { atm }}$ as current atmospheric $\mathrm{CO}_{2}$ values of $\sim 400$ parts per million by volume (ppmv) are at the highest levels of the past million-year time frame (Caldeira and Wickett, 2003; Hoegh-Guldberg et al., 2007; Hönisch et al., 2012). The wide variety of proxies developed for deep time (extended to the Paleozoic era) paleo $\mathrm{CO}_{2}$ reconstruction includes fossil plant stomata, stable carbon isotopes in paleosols and Bryophytes, and marine alkenones (reviewed for the Cretaceous time frame by Wang et al., 2014). At timescales shorter than 1 million years, paleo- $\mathrm{CO}_{2}$ and $\mathrm{pH}_{\mathrm{sw}}$ analyses are derived mostly from air bubbles in ice cores (Monnin et al., 2001; Petit et al., 1999; Vinther et al., 2009) and boron isotopic composition $\left(\delta^{11} \mathrm{~B}\right)$ from carbonate skeletons of foraminifera (Foster, 2008; Hönisch and Hemming, 2005; Hönisch et al., 2009; Palmer et al., 2010; Palmer and Pearson, 2003; Sanyal et al., 1995) and corals (Douville et al., 2010; Gaillardet and Allegre, 1995; Liu et al., 2009; Pelejero et al., 2005; Shinjo et al., 2013; Wei et al., 2009). Skeletal $\delta^{11} \mathrm{~B}$ values are used for paleo $\mathrm{pH}$ reconstruction as they relate to ambient waters' $\mathrm{pH}$. This relationship is based on the assumptions (1) that internal $\mathrm{pH}$ (i.e. where calcification takes place) is associated with ambient $\mathrm{pH}$, and (2) that in seawater only the charged $\mathrm{B}$ species (borate) with lower $\delta^{11} \mathrm{~B}$ values is incorporated into corals. The $\mathrm{B}$ species distribution and the $\delta^{11} \mathrm{~B}$ of the $\mathrm{B}$ species are $\mathrm{pH}$-dependent. If borate represents the only source of $\mathrm{B}$ in the skeletons of corals, than its $\delta^{11} \mathrm{~B}$ is equal to the $\delta^{11} \mathrm{~B}$ of the coral. Therefore, the $\delta^{11} \mathrm{~B}$ of corals is utilized as a proxy of ocean $\mathrm{pH}$ levels at the time of calcification.

It is important to bear in mind that the internal $\mathrm{pH}$ often differs from ambient $\mathrm{pH}$ as the combined result of geochemistry and physiology, thus changing the $\delta^{11} \mathrm{~B}_{\text {coral }}-\delta^{11} \mathrm{~B}_{\mathrm{sw}}$ relationship. Environmental factors that may affect coral's internal $\mathrm{pH}$ include food supply, light intensity, depth or temperature elevation (e.g. Dissard et al., 2012; Hönisch et al., 2004; Reynaud et al., 2004). However, for zooxanthellate corals, the most prominent process raising the coral's internal $\mathrm{pH}$, is photosynthesis carried by its algal symbionts (Laurent et al., 2013; Venn et al., 2011, 2013). Thus, high photosynthesis rates will lead to elevated internal $\mathrm{pH}$ and therefore higher $\delta^{11} \mathrm{~B}$. This photosynthesis-pH- $\delta^{11} \mathrm{~B}$ interrelation was noted both for symbiont-bearing foraminifera (Hoenisch et al., 2003) and corals (Hemming et al., 1998).

Thermally bleached corals however show diminished symbiont photosynthesis (Glynn, 1996) causing a concomitant drop in $\mathrm{pH}$ measured at the corals diffusive boundary layer (DBL) (Al-Horani, 2005). While the interaction of coral biology with its internal $\mathrm{pH}$ (known as vital effects) has been previously quantified as ca. $0.3-0.6 \mathrm{pH}$ units elevation in a "healthy" state (McCulloch et al., 2012; Trotter et al., 2011), the change in physiology due to coral bleaching is hypothesized to push $\mathrm{pH}$ difference beyond the natural vital effect, decoupling internal and ambient $\mathrm{pH}$, skewing $\delta^{11} \mathrm{~B}$ derived $\mathrm{pH}_{\mathrm{sw}}$ estimations (e.g. $\mathrm{pH}_{\mathrm{sw}}$ during 1998 mass bleaching from Wei et al., 2009), and by that, enabling the use of $\delta^{11} \mathrm{~B}$ as a proxy for paleo-bleaching. This approach was recently challenged by Schoepf et al. (2014b), who reported no difference in $\delta^{11} \mathrm{~B}$ signal imprinted in the skeletons of corals that experienced short-term (up to 6 weeks) bleaching event. We hypothesize however, that longer bleaching events, and higher resolution sampling techniques, may allow the detection of the boron-bleaching signature in coral skeletons.

In this study, we examined the signature of coral bleaching manifested in the $\delta^{11} \mathrm{~B}$ values of coral skeletons using experimentally and naturally bleached specimens. Through the use of laser ablation, high-resolution sampling of the coral skeleton deposited while in a bleached state, we quantify a boron bleaching signature. We applied this proxy to published coral $\delta^{11} \mathrm{~B}$ records to investigate the occurrence of coral bleaching since the Last Glacial Maximum.

\section{Materials and methods}

\subsection{Experimentally induced Porites sp. bleaching}

\section{Coral Culturing}

Two adjacent Porites sp. colonies were collected at a $10 \mathrm{~m}$ depth in the Gulf of Aqaba, in the northern Red Sea 
$\left(29^{\circ} 30^{\prime} 06^{\prime \prime} \mathrm{N}, 34^{\circ} 55^{\prime} 00^{\prime \prime} \mathrm{E}\right)$. The coral was cut into $2 \times 2 \mathrm{~cm}$ "nubbins" and left to recover in controlled laboratory conditions $\left(23^{\circ} \mathrm{C}, \mathrm{pH}\right.$ of 8.17 and salinity of $\left.40.7 \mathrm{psu}\right)$ for 3 weeks prior to starting the experiment. Nubbins were separated into two groups - "control" and "heat shock" - and maintained for 8 months (November 2008 to June 2009) in open-system water tables with an input flow rate of $\sim 2.0 \mathrm{~L} \mathrm{~min}^{-1}$ and constant light of an average of $150 \mu \mathrm{mol}$ photons $\mathrm{m}^{-2} \mathrm{~s}^{-1}$. For the control corals temperature varied between $22-24^{\circ} \mathrm{C}$, reflecting seasonal temperature changes in the Gulf of Aqaba, while heat shock treatment temperatures were controlled with a thermostat to induce bleaching (30-32 ${ }^{\circ} \mathrm{C}$; January-March) and recovery $\left(23-25^{\circ} \mathrm{C}\right.$; AprilJune). Temperature fluctuations are outlined for both control and heat shock treatments in the Supporting information (Table S1 in Supplement). Since the experiment was carried in open system, (i.e. with direct connection with the sea) $\mathrm{pH}$ and salinity levels remained in the natural range for the Gulf of Aqaba, $8.20 \pm 0.01$ (SD) pH units and $40.60 \pm 0.08$ (SD) ppt, respectively, throughout the experiment. Nubbins were stained at the beginning of the experiment with Alizarin Red $S$ to identify the start of newly deposited skeleton during the experimental period.

$F_{\mathrm{v}} / F_{\mathrm{m}}$ values were measured approximately every 2 days for the first 3 weeks of the experiment until bleaching was seen. Twelve dark-adapted samples were measured for each treatment using the single turnover flash of over $10000 \mu \mathrm{E}$ on a fast repetition rate fluorometer (FRRF, FIRe system, Satlantic, Halifax, Nova Scotia, Canada).

Oxygen and $\mathrm{pH}$ were measured with microelectrodes in the diffusive boundary layer (DBL) of a healthy and bleached coral during the bleached period (Supplement Fig. S2). At the end of the experiment, the tissue of all corals was removed using a high-pressure airbrush.

\subsection{Natural occurring Stylophora pistillata bleaching}

A Stylophora pistillata fragment was taken from the coral documented by Nir et al. (2014) to undergo bleaching during summer 2010. The coral skeleton was sliced, cleaned and measured for $\delta^{11} \mathrm{~B}$ using the procedures described in the next section. After LA-MC-ICP-MS measurements, coral slices were polished to a thickness of $\sim 0.5 \mathrm{~mm}$ on a microscope slide and photographed through a light microscope. Density bands (annual growth bands) were analyzed as gray intensity of pixels along the measurements path using ImageJ software.

\section{$2.3 \quad \delta^{11} B$ analysis}

For boron analysis, the coral skeletons were sliced and ground to flatten the surface and then immersed in an ultrasonicated Milli-Q water bath for 5 min to remove any particles. Sodium Hypochlorite $(\mathrm{NaClO})$ was used to remove any organics and finally samples were washed with Milli-Q wa- ter and Acetone (full cleaning procedure is detailed in the supplementary information). In this study we used laser ablation for the determination of $\delta^{11} \mathrm{~B}$ instead of bulk analysis of a dissolved material which requires wet chemistry and rigorous cleaning steps. Laser ablation was applied on the ground, cleaned and bleached surfaces of the sliced skeletons. From the experimentally bleached Porites sp. corals, a total of six coral nubbins were analyzed for $\delta^{11} \mathrm{~B}$ using UV femtosecond LA-MC-ICP-MS, two from the control treatment and four from the bleaching treatment. From the naturally bleached $S$. pistillata coral we used one branch. By using a femtosecond (fs) laser ablation system we avoided issues such as thermal fractionation and matrix effects that can occur using nanosecond lasers when using glass standards for carbonate samples (Fietzke et al., 2010; Horn and von Blanckenburg, 2007). Furthermore, the fs-laser ablation technique (ultra-short $\sim 200$ fs pulses) allows for fast and accurate determination of the isotopes in the coral skeleton with minimal melting of the material caused by heat transfer.

$\delta^{11} \mathrm{~B}$ analysis was performed using a Thermo FinniganNeptune MC-ICP-MS, connected to a UV fs $\left(10^{-15} \mathrm{~s}\right)$ laser for ablation (Horn and von Blanckenburg, 2007). NIST SRM 610 was used as the reference material for bracketing. Standard error for coral fragments treatments was less than $0.30 \%$ o $(2 \sigma)$.

\section{$2.4 \mathrm{pH}$ calculation based on Boron isotopic composition}

Since temperature variation in the experiment was high (23$32^{\circ} \mathrm{C}$ ), we had to consider the chemical effect of temperature on $\delta^{11} \mathrm{~B}$ of borate which accompanies the physiological effect of symbiont expulsion. In order to compensate for this effect, $\mathrm{pH}$ levels were calculated based on $\delta^{11} \mathrm{~B}$ values from the Porites sp. experiment using the equation:

$\mathrm{pH}=\mathrm{pK}_{\mathrm{B}}-\log \left(-\frac{\delta^{11} \mathrm{~B}_{\mathrm{sw}}-\delta^{11} \mathrm{~B}_{\text {coral }}}{\delta^{11} \mathrm{~B}_{\mathrm{sw}}-\alpha_{\mathrm{B}} \times \delta^{11} \mathrm{~B}_{\text {coral }}-\left(\alpha_{\mathrm{B}}-1\right) \times 10^{3}}\right)$,

where the isotopic composition of sea water $\left(\delta^{11} \mathrm{~B}_{\mathrm{sw}}\right)$ is $39.5 \%, \alpha_{\mathrm{B}}$ is the fractionation factor $\left({ }^{11-10} \mathrm{~K}_{\mathrm{B}}\right)$ between $\mathrm{B}(\mathrm{OH})_{4}^{-}$and $\mathrm{B}(\mathrm{OH})_{3}$ of 1.0272 (Klochko et al., 2006) and the equilibrium constant $\mathrm{pK}_{\mathrm{B}}$ was calculated for each data point with its coincident temperature and salinity following Dickson (1990) (Table S1). This pH calculation takes into account the effect of temperature on $\delta^{11} \mathrm{~B}_{\text {Borate }}$.

Seeing $\delta^{11} \mathrm{~B}$ as a $\mathrm{pH}$ indicator, we consider these $\mathrm{pH}$ values as the estimated $\mathrm{pH}$ at the site of calcification and present the difference of a $\mathrm{pH}$ value from the normal (at point 0 ) as $\left(\Delta \mathrm{pH}_{i}=\mathrm{pH}_{0}-\mathrm{pH}_{i}\right)$ (Fig. 1).

\subsection{Previously published $\delta^{11} B$ records examination}

Following our experimental results that showed a distinctive bleaching signature in coral's $\delta^{11} \mathrm{~B}$ values, we examined previously published coral and foraminifera's $\delta^{11} \mathrm{~B}$ records 


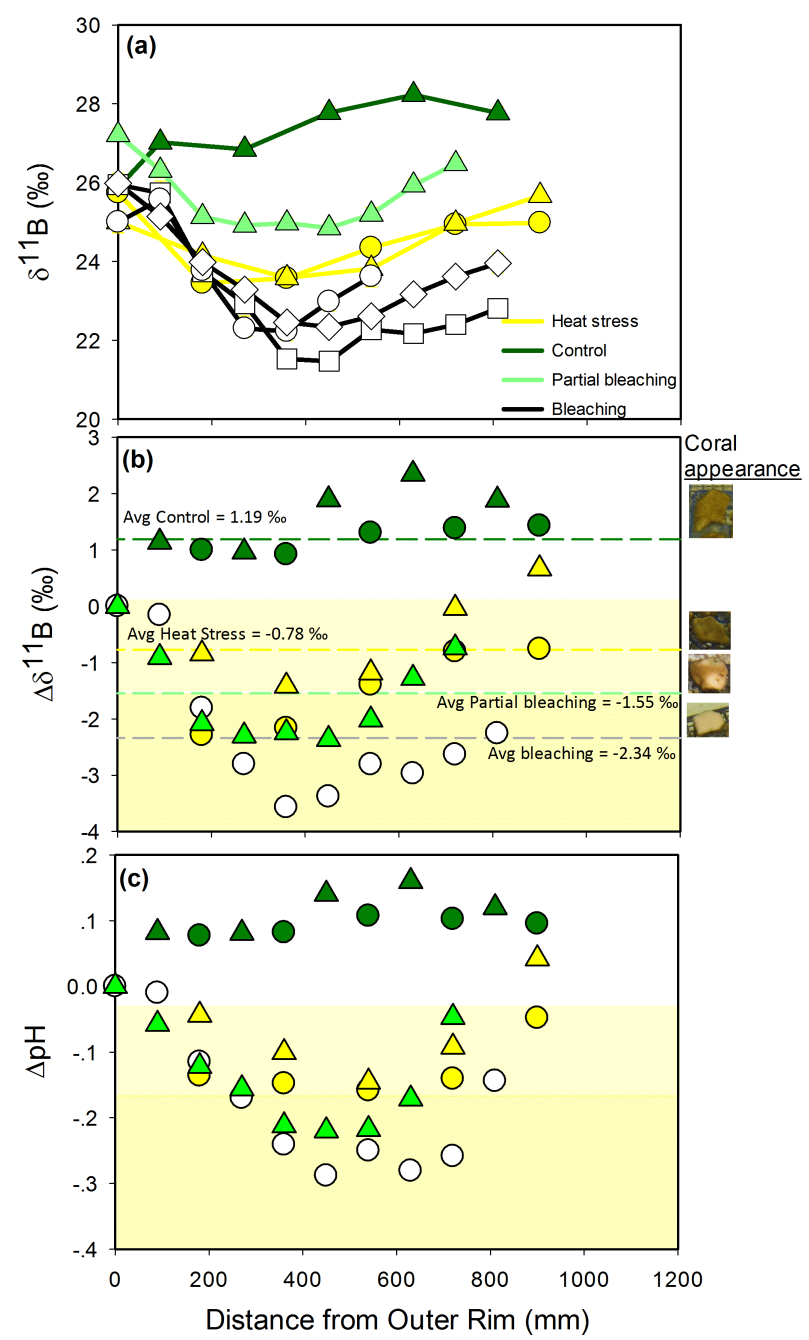

Figure 1. $\delta^{11} \mathrm{~B}$ measurements of coral skeletons following different bleaching situations. (a) Dark green symbols represent control coral measurements, yellow symbols represent heatstressed corals, while bright green and white symbols represent partially and fully bleached corals, respectively. Values of $\delta^{11} \mathrm{~B}=\left[{ }^{11} \mathrm{~B} /{ }^{10} \mathrm{~B}\right]_{\text {sample }} /\left[{ }^{11} \mathrm{~B} /{ }^{10} \mathrm{~B}\right]$ NIST 610 standard $-1 \times 1000$. Values are given in parts per mil $(\% \circ)$ standard error is within the size of symbols $(\leq 0.30 \%, 2 \sigma)$. Dark and bright green triangles, white diamonds and yellow triangles data series were subtracted with $-2 \%$ o to compensate for a change in instrumental setup (detailed in SOM). (b) Relative change from outer rim value for each sample $\left(\Delta \delta^{11} \mathrm{~B}\right)$. All rim values (at $\left.0 \mu \mathrm{m}\right)$ were equaled to zero and the change in $\delta^{11} \mathrm{~B}$ values was plotted for each transect along the growth axis. Positive values equal an enrichment in values while negative values are depleted relative to the rim value. Dashed lines and above written values represent the average $\Delta \delta^{11} \mathrm{~B}$ for a coral bleaching state. Coral's appearance during the heated stage of the experiment is illustrated by the nubbins pictures on the right side. (c) Relative $\mathrm{pH}$ change from outer rim value for each sample $(\Delta \mathrm{pH}) . \mathrm{pH}$ values are calculated from $\delta^{11} \mathrm{~B}$ using temperature corrected $\mathrm{pK}_{B}$ in order to compensate for the temperature effect on $\delta^{11}$ B Borate. for $\delta^{11} \mathrm{~B}$ drops resembling the bleaching signature evidenced in our experiment. Our search was focused on the time frame of the present day to the penultimate deglaciation $(\sim 125 \mathrm{kyr} \mathrm{BP})$, when global temperatures were comparable to present day values (Schmidt et al., 2006). $\delta^{11} \mathrm{~B}$ and calculated $\mathrm{pH}$ values, as well as SST and atmospheric $\mathrm{CO}_{2}$ data, were retrieved from relevant publications' tabulated data if available. Data of Gaillardet and Allegre (1995), which were not available, were recovered from graphics using GETDATA graph digitizer (http://getdata-graph-digitizer.com/). SST data for the open sea as close as possible to Arlington Reef (Lat. $17^{\circ} \mathrm{S}$, Lon. $148^{\circ} \mathrm{E}, \mathrm{GBR}$ ) was taken from NOAA ERSST-3b database (http://nomads.ncdc.noaa.gov/las/getUI. do) monthly reconstruction (Smith et al., 2008). Meta data for the reviewed coral records are presented in the supporting information (Table S2). Relative $\delta^{11} \mathrm{~B}$ drops $\left(\Delta \delta^{11} \mathrm{~B}\right)$ in published $\delta^{11} \mathrm{~B}$ records were calculated as the difference between a specific $\delta^{11} \mathrm{~B}$ value and the average $\delta^{11} \mathrm{~B}$ of the whole data series in which it belongs. For the comparison of experimental results and previous (low resolution) records, the effect of sampling resolution was estimated and corrected by averaging $\delta^{11} \mathrm{~B}$ throughout the whole experimental time series (Fig. 1).

\section{Results and discussion}

\subsection{Experimental bleaching}

Oxygen and $\mathrm{pH}$ micro-sensor analysis in the DBL of a bleached massive Porites sp. revealed a decrease in $\mathrm{pH}$ down to $7.85(0.32 \mathrm{pH}$ units below ambient $\mathrm{pH}$ values) during light conditions with no increase in oxygen, as opposed to a healthy coral which exhibited an increase in oxygen production and a re-alkalization of the DBL under the same light conditions following a period of dark incubation (Supporting information, Fig. S2). These measurements serve as validation of an already quantified phenomenon of reduced $\mathrm{pH}$ in the DBL as a result of bleaching (Al-Horani, 2005). While corals are known to elevate the $\mathrm{pH}$ at the site of calcification relative to ambient seawater (Venn et al., 2011), reduced seawater $\mathrm{pH}$ resulting from the chemical dissolution of $\mathrm{CO}_{2}$ has been shown to reduce the calcifying medium $\mathrm{pH}$, overwhelming up-regulatory compensation (Venn et al., 2013). Theoretically, the same would hold true for biological reductions of $\mathrm{pH}$ in the DBL evident in micro-sensor measurements.

Corals' responses to the heat stress conditions in the experimentally induced bleaching experiment varied individually (Fig. S1), where two nubbins showed no apparent bleaching while the other two were either partially or fully bleached. Fully and partially thermally induced bleached corals displayed a $\delta^{11} \mathrm{~B}$ drop $\left(\Delta \delta^{11} \mathrm{~B}\right)$ of $2.2-3.7 \%$ relative to their recovered outer rim values, descending to $21.5 \%$, which corresponds to a $\mathrm{pH}$ drop $(\Delta \mathrm{pH})$ of 0.29 units (Fig. 1). The 
decrease of ca. $0.3 \mathrm{pH}$ units as a result of diminished photosynthesis coincides with previous measurements of internal and DBL pH in light-dark or bleaching manipulations (Al-Horani, 2005; Venn et al., 2011). This $\mathrm{pH}$ drop is also corrected for temperature effect on $\delta^{11} \mathrm{~B}$ Borate (detailed in Sect. 2.4) and therefore should be considered as the result of physiological change (i.e. coral bleaching). Due to the high resolution of sampling ( $\sim 45 \mu \mathrm{m}$ equals about $2-3$ weeks of skeletal deposition) we were able to record low $\delta^{11} \mathrm{~B}$ values at the time of bleaching. In order to demonstrate the effect of sampling resolution and to allow comparison of our results with some lower resolution studies, we calculated the average values for the whole experiment ( $\sim 7$ months) consisting of unbleached acclimation, heat stress driven bleaching and recovery. In this case, partially and fully bleached corals showed $\delta^{11} \mathrm{~B}$ drop of -1.55 and $-2.34 \%$ (respectively, Fig. 1). Interestingly, heat-stressed corals showed a $\delta^{11} \mathrm{~B}$ drop of $-0.78 \%$ even though they were not apparently bleached. This finding contradicts previous reports of increased $\delta^{11} \mathrm{~B}$ in elevated temperatures (Dissard et al., 2012) implying a distinctive difference between the effect of "normal" high temperatures within the natural habitat's range increasing photosynthesis and calcification rates, and the effect of heat-stress-temperature conditions depressing coral physiology.

\subsection{Natural bleaching}

A mesophotic (60 m depth) S. pistillata coral documented to go through a seasonal summer bleaching (Nir et al., 2014) showed a $\delta^{11} \mathrm{~B}$ drop of $\Delta \delta^{11} \mathrm{~B}=-5.1 \%$ o during the bleached period (Fig. 2). The "bleached" low $\delta^{11} \mathrm{~B}$ value falls on the value calculated with boron isotope equilibrium constant $\left({ }^{11-10} \mathrm{~K}_{\mathrm{B}}\right)$ of Klochko et al. (2006) (not accounted for vital effect) while the "healthy" high $\delta^{11} \mathrm{~B}$ value coincides with the normal value measured for this species at $\mathrm{pH} 8.2$ (with symbionts) (Krief et al., 2010). However, the high magnitude of $\delta^{11} \mathrm{~B}$ change found for the bleached period is somewhat surprising due to the fact that baseline levels of productivity were documented to be low for this mesophotic coral (Nir et al., 2014). This result may point to other $\mathrm{pH}$ up-regulation processes, besides photosynthesis, that are also weakened during bleaching.

In contrast to our findings, recent explorations of boron isotopes in bleached corals found no effect of short-term bleaching on the skeletal boron signal (Schoepf et al., 2014b). Our study may have been able to capture the depletion in $\delta^{11} \mathrm{~B}$ due to (1) the use of high-resolution sampling across the coral growth axis and (2) the relatively long bleached period, allowing a coral to precipitate "new" aragonite encompassing the boron signal of bleaching. This allows for an intricate time series comparison within the same individuals enabling the detection of relative changes in the skeletal boron isotopes at multiple time points before, during and after a bleaching event sustained over approximately

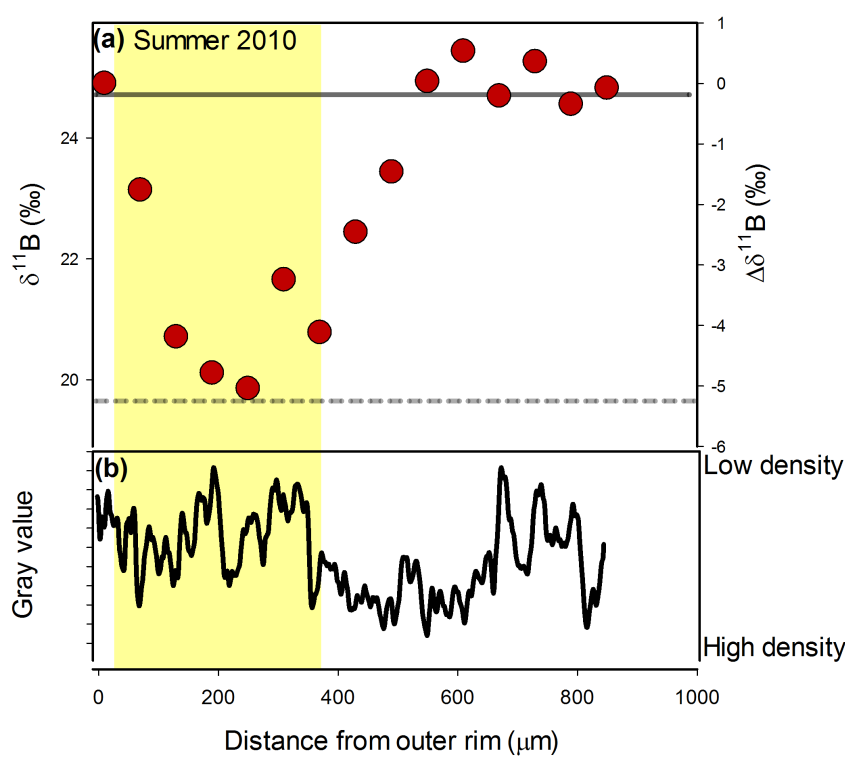

Figure 2. (a) $\delta^{11} \mathrm{~B}$ measurements of mesophotic (60 m) Stylophora pistillata coral documented to undergo bleaching during summer 2010 (Nir et al., 2014). (b) Skeleton density, reported as the gray value of pixels along the ablation transect. Yellow shaded area represents the low-density skeleton band deposited in summer 2010 . Solid and dashed gray lines represent the expected $\delta^{11} \mathrm{~B}$ value for $\mathrm{pH}_{\mathrm{sw}}=8.2$ calculated with boron isotope equilibrium constant $\left({ }^{11-10} \mathrm{~K}_{\mathrm{B}}\right)$ of Klochko et al. (2006) (not accounted for vital effect) and an empirical coefficient specific to this species (with symbionts) by Krief et al. (2010), respectively.

3 months. The duration of natural coral bleaching events varies in time scale, from a few days to prolonged periods over several months or seasons. The boron bleaching signature would likely not be recorded in the case of short durations of bleaching, simply because not enough aragonite will have precipitated to allow for analysis. However, the depletion of $\delta^{11} \mathrm{~B}$ during bleaching may be captured for longer and more pronounced bleaching events or by using fine-scale measurements (e.g. laser ablation) as evidenced in our study. It is noteworthy that searching for paleo bleaching event using the boron isotope signature will only allow identification of major events (which are probably of higher environmental significance) rather than short, anecdotal events. Furthermore, the high-resolution sampling implied here, which might seem irrelevant for paleo-climate studies (e.g. pH reconstruction over glacial cycles), is shown to be of crucial importance when looking for biological phenomena.

\subsection{Establishment of the $\delta^{11} B$ bleaching proxy}

Our experimental results showed a decreased $\mathrm{pH}$ at the DBL accompanied by a sharp $\delta^{11} \mathrm{~B}$ drop for bleached coral held at constant ambient $\mathrm{pH}_{\mathrm{sw}}$. A field "ground truth" for this boron bleaching signature was found in a naturally bleached mesophotic (60 m depth) S. pistillata coral. Further evi- 

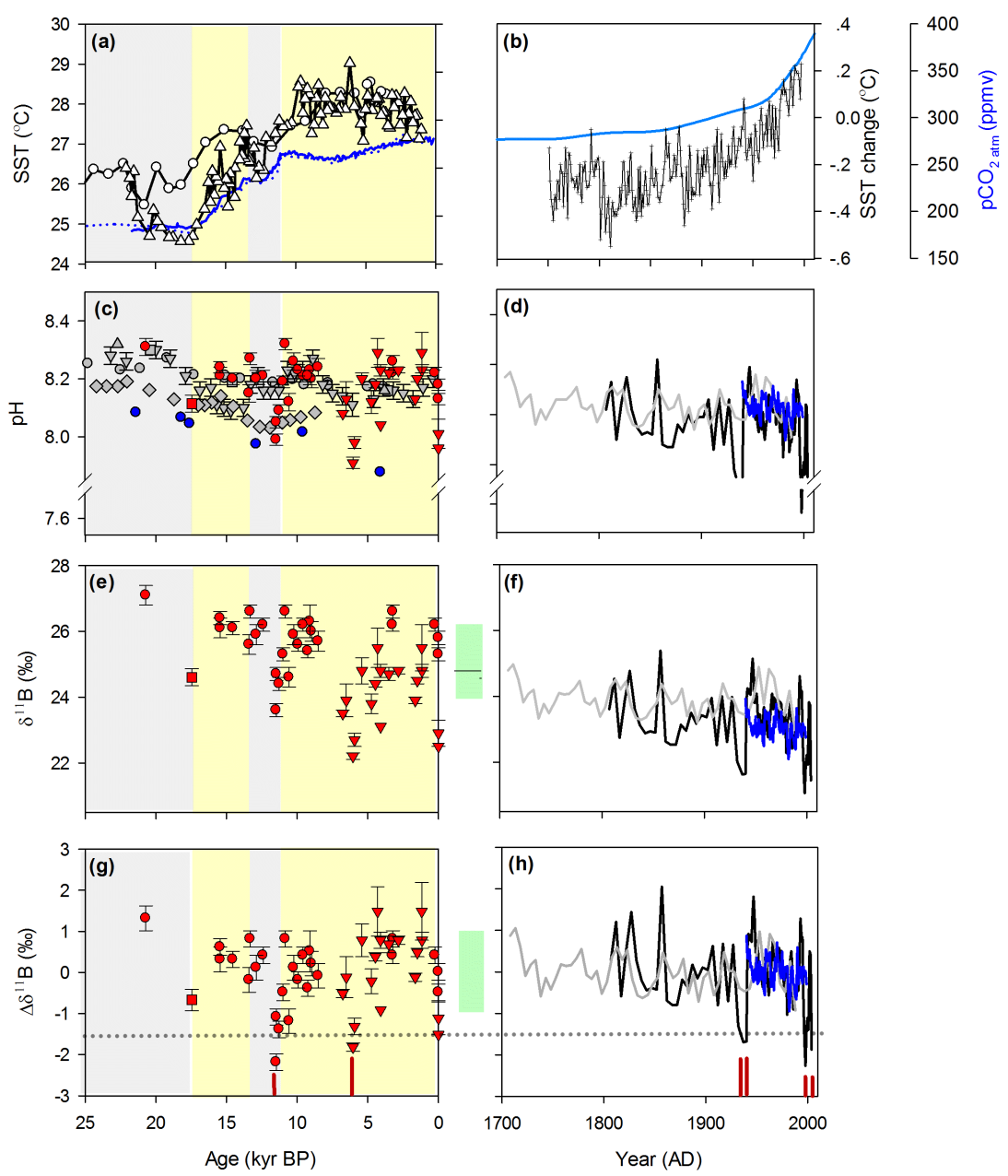

Figure 3. 25000 year records of paleo-ocean climate and pH (a-d) and boron isotopic compositions in coral skeletons (e-h). Blue lines (a-b) represent atmospheric $p \mathrm{CO}_{2}$ measured in gas trapped in ice cores (Monnin et al., 2001, 2004; Petit et al., 1999; Robertson et al., 2001) and direct measurements (Tans, 2012), open symbols represent SST records (triangles - South China Sea, Steinke et al., 2008, circles - Western Caribbean sea, Schmidt et al., 2006, and crosses - modern tropics (Indian and Pacific oceans), Wilson et al., 2006). $\delta^{11} \mathrm{~B}$ derived $\mathrm{pH}$ from foraminifera (ocean surface in gray symbols - circles, Foster, 2008; inverted triangles, Palmer and Pearson, 2003; rectangles, Hönisch et al., 2009; diamonds, Palmer et al., 2010 and triangles, Hönisch and Hemming, 2005; Deep waters pH in blue symbols, Yu et al., 2010) and coral (red symbols - circles, Douville et al., 2010, inverted triangles, Liu et al., 2009 and rectangles, Gaillardet and Allegre, 1995; grey, Pelejero et al., 2005 blue, Shinjo et al., 2013 and black, Wei et al., 2009 lines) is shown in (c-d). The boron isotopic compositions, on which coral pH is based, are presented in $(\mathbf{e}-\mathbf{f})$. The difference of $\delta^{11} \mathrm{~B}$ from the average value in record $\left(\Delta \delta^{11} \mathbf{B}\right)$ is shown in $(\mathbf{g}-\mathbf{h})$ together with a dotted line under which data points are suggested to represent coral bleaching. Green bars and line within represent $\delta^{11} \mathrm{~B}$ annual range and average measured at unbleached coral (Hemming et al., 1998). Red vertical lines mark the timing of suspected bleaching events. Grey and yellow shaded bars represent cold and warm periods, respectively.

dence that $\delta^{11} \mathrm{~B}$ drop can serve as a bleaching proxy can be gathered from a recent coral bleaching event on Australia's Great Barrier Reef (GBR) (Wei et al., 2009). Using a ca. 200-year old Porites, Wei et al. reported low $\delta^{11} \mathrm{~B}$ values $\left(\delta^{11} \mathrm{~B}_{1998}=21.06 \%\right.$ o, $\Delta \delta^{11} \mathrm{~B}_{1998}=-2.3 \%$ and $\delta^{11} \mathrm{~B}_{2001}=21.93 \%$ o, $\Delta \delta^{11} \mathrm{~B}_{2001}=-1.4 \%$, Fig. 2) during the 1998 and early 2002 bleaching events. These low values, measured at times of bleaching events, are similar to the low $\delta^{11} \mathrm{~B}$ values recorded in our experimentally bleached coral.
Based on our laboratory results as well as on natural records of Porites sp. bleaching, we define the boron bleaching proxy as $\delta^{11} \mathrm{~B}$ drop of at least $1.5 \%$. This value was chosen by estimating the average $\Delta \delta^{11} \mathrm{~B}$ for ca. 1 year in the experimentally bleached corals, simulating the common paleo $\mathrm{pH} \delta^{11} \mathrm{~B}$ records temporal resolution (Table $\mathrm{S} 2$ ). This value also falls outside the range of the natural variability measured in Porites lobata coral skeleton throughout two annual cycles (Hemming et al., 1998) (Fig. 3, green boxes). In applying this proxy to identify paleo-bleaching events, 
we also inspected concomitant paleo-SST, air temperature and $p \mathrm{CO}_{2}$ atm records to provide support for our conclusions (Fig. 3). In cases where a drastic drop in $\delta^{11} \mathrm{~B}$ is associated with high SST or severe warming rather than $p \mathrm{CO}_{2}$ increase, we propose that a thermal stress may have induced bleaching and resulted in the low $\delta^{11} \mathrm{~B}$ values, rather than a $\mathrm{pH}_{\mathrm{sw}}$ drop.

It is important to note that most coral paleo-reconstruction studies focus on the analysis of a single core due to the difficulty in preparation and analysis of the samples. Coral bleaching however can be spatially heterogeneous with neighboring individuals exhibiting variable responses (Baker et al., 2008) making broad generalizations difficult. Thus if a depletion in $\delta^{11} \mathrm{~B}$ values is not found where bleaching is expected this does not necessarily mean that coral bleaching did not occur on that reef at some point in time. For example, in a recent analysis of a massive Porites core from Guam (Shinjo et al., 2013), no bleaching signal is found in the $\delta^{11} \mathrm{~B}$ signature from the period of 1940-2000. This does not rule out bleaching in the region. In fact, slight depressions in the $\delta^{11} \mathrm{~B}$ values $\left(-0.5>\Delta \delta^{11} \mathrm{~B}>-1 \%\right.$ o coincide with $\mathrm{El}$ Niño years and may indicate physiological heat stress of the coral. Alternatively, when the boron bleaching signature is evident in fossil coral core samples, as outlined in the coming examples, based on our experimental findings it may indicate that coral bleaching has occurred.

\subsection{Coral bleaching events recorded since the Last Glacial Maximum}

Over the past 800000 years of glacial/interglacial cycles, atmospheric $\mathrm{CO}_{2}$ oscillated between 180-280 ppmv, with an increase of less than $30 \mathrm{ppmv}$ from the Holocene until the beginning of the industrial revolution $(\sim 1860)$. Ocean surface's $\mathrm{pH}$ paleo-records (based on coral's $\delta^{11} \mathrm{~B}$ measurements) exhibit higher magnitude variations in comparison to atmospheric $p \mathrm{CO}_{2}$ (Fig. 3). These shifts have been interpreted as major oceanographic events such as alterations of ocean circulation stemming from upwelling of cold, low pH waters to the surface (Douville et al., 2010; Liu et al., 2009), decoupling the tight relation of $p \mathrm{CO}_{2}$ atm and $\mathrm{pH}_{\mathrm{sw}}$ on a regional scale. However, following the results presented in this paper, we suggest an alternative explanation for the $p \mathrm{CO}_{2}$ atm and $\mathrm{pH}_{\mathrm{sw}}$ decoupling, where a severe drop of the coral $\delta^{11} \mathrm{~B}$ values is associated with high or rapidly increasing SST rather than an increasing $p \mathrm{CO}_{2}$ atm, this drop may be the geochemical signature of coral bleaching and not of a $\mathrm{pH}_{\mathrm{sw}}$ decline.

We inspected published paleo-pH records from coral skeletons through the Eemian interglacial stage $(\sim 130 \mathrm{kyr} B P)$ and identified six suspected data points (Fig. 3 - red vertical lines) that meet our boron bleaching signature definition of a depletion in $\delta^{11} \mathrm{~B}$ values greater than $1.5 \%$ orelative to the average values measured in that series (Fig. 3, dotted line). Supported with concomitant paleo climate records, we make a case for these instances that represent potential bleaching events rather than an actual ocean acidification.

\subsubsection{0th century, GBR}

Pelejero et al. (2005) measured a 280 -year $\delta^{11} \mathrm{~B}$ record of Porites sp. and reported the lowest $\delta^{11} \mathrm{~B}$ value for the last 3 centuries at Flinders Reef, GBR, ca. 1988 (using 5-year averages) (22.99\%o, $7.91 \mathrm{pH}$ units) with an overall trend of low $\mathrm{pH}$ values associated with positive values of the Interdecadal Pacific Oscillation (IPO) index (El Niño-like conditions), interpreted to result in low rates of water exchange at the Flinders Reef's lagoon. However, high-resolution inspection of $1987-1988$ reveals that the lowest $\delta^{11} \mathrm{~B}$ value was recorded during the warmest month (February 1988, $\delta^{11} \mathrm{~B}=22.26 \%$, stands $1.65 \%$ o below the multi-annual average) even though wind speed, normally linked to a highlagoonal water exchange, was high that month. Since this low $\delta^{11} \mathrm{~B}$ value also coincides with warm SST and the 1988 worldwide mass bleaching (Williams and Bunkley-Williams, 1990), it is likely that the reported low $\delta^{11} \mathrm{~B}$ value is due to heat stress or coral bleaching. This value was preceded by a period of lower values that commenced at the transition from cooler to warmer SST during the austral summer of 1987 and could indicate a sustained bleaching period, such as was seen in the $\delta^{11} \mathrm{~B}$ values of our experimentally bleached coral skeletons.

Additional low $\delta^{11} \mathrm{~B}$ values $\left(\delta^{11} \mathrm{~B}<21.65 \%\right.$, stands $1.67 \%$ below the multi-annual average ) were recorded for Arlington reef at two sampling points during 1937-1940 (Wei et al., 2009) that coincide with a trend of rapidly warming SST (Smith et al., 2008) (Fig. S2), suggested to indicate pronounced bleached periods within this time frame.

\subsection{2 $6 \mathrm{Kyr} \mathrm{BP,} \mathrm{SCS}$}

Liu et al. (2009) measured Porites sp. $\delta^{11} \mathrm{~B}$ from the South China Sea (SCS) and reported a $\delta^{11} \mathrm{~B}$ drop, at $\sim 6 \mathrm{kyr}$ BP $\left(\Delta \delta^{11} \mathrm{~B}=-1.82 \%\right.$ ) interpreted by the authors as low $\mathrm{pH}$ during the Holocene thermal optimum $(\sim 5-9 \mathrm{kyr}$ BP). This period was suggested to be characterized by an intensified summer monsoon that resulted in strengthened upwelling and introduced low $\mathrm{pH}$ deep water to the surface of SCS. However, no sign of cold deep water upwelling is evidenced in the reported SST values (Yu et al., 2005). Furthermore, $\mathrm{Mg} / \mathrm{Ca}$ derived SST records related to SCS upper waters $(0-30 \mathrm{~m})$ temperature show a peak in SST around $6 \mathrm{kyr}$ BP (Steinke et al., 2008) ascending to $29^{\circ} \mathrm{C}$. Translating pH values to $p \mathrm{CO}_{2}$ (using $\mathrm{CO} 2$ sys software, Pierrot and Wallace, 2006) shows that although Holocene $p \mathrm{CO}_{2}$ atm was relatively stable (260-290 ppmv, not including the 20th century), reported $\mathrm{pH}$ values are equivalent to much higher $p \mathrm{CO}_{2}$ levels, up to $571 \mathrm{ppmv}$ at $6 \mathrm{kyr} \mathrm{BP}$. This drop of $\delta^{11} \mathrm{~B}$ (at $6 \mathrm{kyr} \mathrm{BP}$ ) corresponds better with high SST, rather than a drastic increase in $p \mathrm{CO}_{2}$ or upwelling introducing low $\mathrm{pH}$ water to 
the surface. Therefore, we propose that the low $\delta^{11} \mathrm{~B}$ values imprinted in SCS corals $6 \mathrm{kyr} \mathrm{BP}$ are the result of a bleaching event.

\subsection{Kyr BP, Central Pacific}

Both Gaillardet and Allegre (1995) and Douville et al. (2010) reported a severe drop of $\delta^{11} \mathrm{~B}$ measured in central subequatorial pacific corals (Acropora sp. from Tahiti, Gaillardet and Allegre, 1995 and Porites sp. from Marquesas Is., Douville et al., 2010) at the end of the Younger Dryas period $\sim 11.5 \mathrm{kyr} \mathrm{BP}\left(\Delta \delta^{11} \mathrm{~B}=-2.18 \%\right.$ ) . This drop deviated from the otherwise stable values measured before and after this time period by more than $1.5 \%$ (interpreted as $\mathrm{pH}$ drop $\sim 0.2$, Douville et al., 2010) (Fig. 2). In these studies, diagenesis was not examined, so the low $\delta^{11} \mathrm{~B}$ values should be taken with cautious. Douville et al. (2010) attributed this dip to sustained La Niña-like conditions which introduced lower $\mathrm{pH}$ cold waters in the central sub-equatorial Pacific (Douville et al., 2010). The equatorial Pacific SST gradient ( $\triangle \mathrm{SST}$ ), which coincides with the strength of westward low $\mathrm{pH}$ water advection (Koutavas et al., 2002), was intensified at the end of Younger Dryas, potentially extending the low $\mathrm{pH}$ "cold tongue" westward closer to the Tahiti Islands. Nevertheless, $\triangle$ SST was only as high as modern times remaining constant throughout the Holocene, while $\delta^{11} \mathrm{~B}$ returned to background values (Fig. 3) (Kienast et al., 2001; Koutavas et al., 2002). The dominance of La Niña patterns at this period is further challenged by alternative suggestions of El Niño conditions prevailing during the Bolling interstadial and the end of Younger Dryas (Koutavas and Sachs, 2008). Furthermore, following the cold Younger Dryas period was a period of rapid warming (Asami et al., 2009; Schmidt et al., 2006), which likely increased seasonal maximum temperatures (Fig. 3). The yearly increases in temperature, the major cause of coral bleaching in the modern era (Baker et al., 2008), could have resulted in a wide spread coral bleaching event $11.5 \mathrm{kyr}$ BP in the central sub-equatorial Pacific. This offers an alternative explanation for the low $\delta^{11} \mathrm{~B}$ values obtained for corals, rather than sustained La Niña-like conditions.

\section{Conclusions}

Coral bleaching exerts a considerable signature on $\delta^{11} \mathrm{~B}$ measurements taken from the scleractinian corals S. pistilata and massive Porites sp. $\left(\Delta \delta^{11} \mathrm{~B}=1.5-5.1 \%\right.$ ) . Employing highresolution femtosecond LA-MC-ICP-MS, we provide evidence that $\delta^{11} \mathrm{~B}$ is sensitive, and highly influenced by the physiological interactions of the photosymbiont and the calcifying organism (i.e., a drop in photosynthetic activity of photosymbionts during bleaching events). Overall, our experimental results, along with previously published data, highlight the challenges of utilizing $\delta^{11} \mathrm{~B}$ as a straight for- ward proxy for paleo- $\mathrm{pH}_{\mathrm{sw}}$. To gain an accurate interpretation of $\delta^{11} \mathrm{~B}$ values, the bleaching state of the organism from which the data are derived must be considered. On the other hand, when supported with concurrent $p \mathrm{CO}_{2}$ atm, foraminifers' $\mathrm{pH}$ and SST records, this proxy opens the door to investigations that utilize $\delta^{11} \mathrm{~B}$ as a paleo-bleaching marker.

While the understanding of temporal dynamics of when/how these events are recorded in coral skeletons still requires examination of additional modern known bleaching events, our findings provide evidence that coral bleaching may not be an exclusively modern phenomenon and we have identified at least two instances since the LGM $(\sim 20 \mathrm{kyr} \mathrm{BP})$ prior to the industrial revolution where coral bleaching likely occurred. If short-term bleaching is indeed untraceable with $\delta^{11} \mathrm{~B}$ measurements (Schoepf et al., 2014b), then the suspected paleo-bleaching events may be a result of longer sustained bleaching events, possibly comparable with contemporary worrisome mass bleaching episodes.

\section{The Supplement related to this article is available online at doi:10.5194/bg-12-5677-2015-supplement.}

Acknowledgements. The experimental work for this paper was conducted as part of J. Fisch's thesis while at Hebrew University in Jerusalem, Israel. The authors would like to acknowledge KlausUwe Richter for all of his analytical support. D. Tchernov and J. Bijma would like to acknowledge financial support from BMBF provided for the project "Reconstruction of past bleaching events using a high resolution microanalysis of $\delta 11 \mathrm{~B}$ " in the framework of the German Israeli collaboration (03V0956). D. F. Gruber would like to acknowledge funding from the National Science Foundation grant \#0920572. G. Dishon would like to acknowledge funding from SBM and Minerva foundation. The authors would also like to acknowledge the Israel National Monitoring Program for the long-term $\mathrm{pH}$ and sea surface temperature data in the Gulf of Aqaba. We thank the two anonymous referees who helped improve this manuscript.

Edited by: A. Shemesh

\section{References}

Al-Horani, F. A.: Effects of changing seawater temperature on photosynthesis and calcification in the scleractinian coral Galaxea fascicularis, measured with $\mathrm{O}_{2}, \mathrm{Ca}_{2}^{+}$and $\mathrm{pH}$ microsensors, Sci. Mar., 69, 347-354, 2005.

Asami, R., Felis, T., Deschamps, P., Hanawa, K., Iryu, Y., Bard, E., Durand, N., and Murayama, M.: Evidence for tropical South Pacific climate change during the Younger Dryas and the BøllingAllerød from geochemical records of fossil Tahiti corals, Earth Planet. Sci. Lett., 288, 96-107, 2009. 
Baker, A. C., Glynn, P. W., and Riegl, B.: Climate change and coral reef bleaching: An ecological assessment of long-term impacts, recovery trends and future outlook, Estuarine, Coast. Shelf Sci., 80, 435-471, 2008.

Brown, B.: Coral bleaching: causes and consequences, Coral Reefs, 16, S129-S138, 1997.

Caldeira, K. and Wickett, M. E.: Anthropogenic carbon and ocean pH, Nature, 425, 365-365, 2003.

Dickson, A. G.: Thermodynamics of the dissociation of boric acid in synthetic seawater from 273.15 to $318.15 \mathrm{~K}$, Deep-Sea Res. Pt. A, 37, 755-766, 1990.

Dissard, D., Douville, E., Reynaud, S., Juillet-Leclerc, A., Montagna, P., Louvat, P., and McCulloch, M.: Light and temperature effects on $\mathrm{d} 11 \mathrm{~B}$ and $\mathrm{B} / \mathrm{Ca}$ ratios of the zooxanthellate coral Acropora sp.: results from culturing experiments, Biogeosciences, 9, 4589-4605, doi:10.5194/bg-9-4589-2012, 2012.

Douville, E., Paterne, M., Cabioch, G., Louvat, P., Gaillardet, J., Juillet-Leclerc, A., and Ayliffe, L.: Abrupt sea surface $\mathrm{pH}$ change at the end of the Younger Dryas in the central subequatorial Pacific inferred from boron isotope abundance in corals (Porites), Biogeosciences, 7, 2445-2459, doi:10.5194/bg7-2445-2010, 2010.

Fautin, D. G. and Buddemeier, R. W.: Adaptive bleaching: a general phenomenon, Hydrobiologia, 530, 459-467, 2004.

Fietzke, J., Heinemann, A., Taubner, I., Böhm, F., Erez, J., and Eisenhauer, A.: Boron isotope ratio determination in carbonates via LA-MC-ICP-MS using soda-lime glass standards as reference material, J. Anal. Atom. Spectrom., 25, 1953-1957, 2010.

Foster, G. L.: Seawater $\mathrm{pH}, p \mathrm{CO}_{2}$ and $\left[\mathrm{CO}_{2}^{-3}\right]$ variations in the Caribbean Sea over the last $130 \mathrm{kyr}$ : A boron isotope and B / Ca study of planktic foraminifera, Earth Planet. Sci. Lett., 271, 254266, 2008.

Gaillardet, J. and Allegre, C. J.: Boron isotopic compositions of corals: Seawater or diagenesis record?, Earth Planet. Sci. Lett., 136, 665-676, 1995.

Glynn, P. W.: Coral reef bleaching: facts, hypotheses and implications, Glob. Change Biol., 2, 495-509, 1996.

Heikoop, J. M., Dunn, J. J., Risk, M. J., Schwarcz, H. P., McConnaughey, T. A., and Sandeman, I. M.: Separation of kinetic and metabolic isotope effects in carbon-13 records preserved in reef coral skeletons, Geochim. Cosmochim. Acta, 64, 975-987, 2000.

Hemming, N. G., Guilderson, T. P., and Fairbanks, R. G.: Seasonal variations in the boron isotopic composition of coral: A productivity signal?, Global Biogeochem. Cy., 12, 581-586, 1998.

Hoegh-Guldberg, O.: Climate change, coral bleaching and the future of the world's coral reefs, Mar. Fresh. Res., 50, 839-866, 1999.

Hoegh-Guldberg, O., Mumby, P. J., Hooten, A. J., Steneck, R. S., Greenfield, P., Gomez, E., Harvell, C. D., Sale, P. F., Edwards, A. J., Caldeira, K., Knowlton, N., Eakin, C. M., Iglesias-Prieto, R., Muthiga, N., Bradbury, R. H., Dubi, A., and Hatziolos, M. E.: Coral reefs under rapid climate change and ocean acidification, Science, 318, 1737-1742, 2007.

Hönisch, B. and Hemming, N. G.: Surface ocean $\mathrm{pH}$ response to variations in $p \mathrm{CO}_{2}$ through two full glacial cycles, Earth Planet. Sci. Lett., 236, 305-314, 2005.

Hönisch, B., Bijma, J., Russell, A. D., Spero, H. J., Palmer, M. R., Zeebe, R. E., and Eisenhauer, A.: The influence of symbiont pho- tosynthesis on the boron isotopic composition of foraminifera shells, Mar. Micropaleontol., 49, 87-96, 2003.

Hönisch, B., Hemming, N. G., Grottoli, A. G., Amat, A., Hanson, G. N., and Bijma, J.: Assessing scleractinian corals as recorders for paleo-pH: Empirical calibration and vital effects, Geochim. Cosmochim. Acta, 68, 3675-3685, 2004.

Hönisch, B., Hemming, N. G., Archer, D., Siddall, M., and McManus, J. F.: Atmospheric Carbon Dioxide Concentration Across the Mid-Pleistocene Transition, Science, 324, 1551-1554, 2009.

Hönisch, B., Ridgwell, A., Schmidt, D. N., Thomas, E., Gibbs, S. J., Sluijs, A., Zeebe, R., Kump, L., Martindale, R. C., Greene, S. E., Kiessling, W., Ries, J., Zachos, J. C., Royer, D. L., Barker, S., Marchitto, T. M., Moyer, R., Pelejero, C., Ziveri, P., Foster, G. L., and Williams, B.: The Geological Record of Ocean Acidification, Science, 335, 1058-1063, 2012.

Horn, I. and von Blanckenburg, F.: Investigation on elemental and isotopic fractionation during $196 \mathrm{~nm}$ femtosecond laser ablation multiple collector inductively coupled plasma mass spectrometry, Spectrochim. Ac. Pt. B, 62, 410-422, 2007.

Kienast, M., Steinke, S., Stattegger, K., and Calvert, S. E.: Synchronous Tropical South China Sea SST Change and Greenland Warming During Deglaciation, Science, 291, 2132-2134, 2001.

Klochko, K., Kaufman, A. J., Yao, W., Byrne, R. H., and Tossell, J. A.: Experimental measurement of boron isotope fractionation in seawater, Earth Planet. Sci. Lett., 248, 276-285, 2006.

Koutavas, A., Lynch-Stieglitz, J., Marchitto, T. M., and Sachs, J. P.: El Niño-Like Pattern in Ice Age Tropical Pacific Sea Surface Temperature, Science, 297, 226-230, 2002.

Koutavas, A. and Sachs, J. P.: Northern timing of deglaciation in the eastern equatorial Pacific from alkenone paleothermometry, Paleoceanography, 23, PA4205, doi:10.1029/2008PA001593, 2008.

Krief, S., Hendy, E. J., Fine, M., Yam, R., Meibom, A., Foster, G. L. and Shemesh, A.: Physiological and isotopic responses of scleractinian corals to ocean acidification, Geochim. Cosmochim. Acta, 74, 4988-5001, 2010.

Laurent, J., Tambutté, S., Tambutté, É., Allemand, D., and Venn, A.: The influence of photosynthesis on host intracellular $\mathrm{pH}$ in scleractinian corals, J. Experiment. Biol., 216, 1398-1404, 2013.

Liu, Y., Liu, W., Peng, Z., Xiao, Y., Wei, G., Sun, W., He, J., Liu, G., and Chou, C.-L.: Instability of seawater $\mathrm{pH}$ in the South China Sea during the mid-late Holocene: Evidence from boron isotopic composition of corals, Geochim. Cosmochim. Acta, 73, 12641272, 2009.

McCulloch, M., Trotter, J., Montagna, P., Falter, J., Dunbar, R., Freiwald, A., Försterra, G., López Correa, M., Maier, C., Rüggeberg, A., and Taviani, M.: Resilience of cold-water scleractinian corals to ocean acidification: Boron isotopic systematics of $\mathrm{pH}$ and saturation state up-regulation, Geochim. Cosmochim. Acta, 87, 2134, 2012.

Monnin, E., Indermuhle, A., Dallenbach, A., Fluckiger, J., Stauffer, B., Stocker, T. F., Raynaud, D., and Barnola, J. M.: Atmospheric $\mathrm{CO}_{2}$ concentrations over the last glacial termination, Science, 291, 112-114, 2001.

Monnin, E., Steig, E. J., Siegenthaler, U., Kawamura, K., Schwander, J., Stauffer, B., Stocker, T. F., Morse, D. L., Barnola, J.M., Bellier, B., Raynaud, D., and Fischer, H.: Evidence for substantial accumulation rate variability in Antarctica during the Holocene, through synchronization of $\mathrm{CO}_{2}$ in the Taylor Dome, 
Dome C and DML ice cores, Earth Planet. Sci. Lett., 224, 45-54, 2004.

Nir, O., Gruber, D. F., Shemesh, E., Glasser, E., and Tchernov, D.: Seasonal Mesophotic Coral Bleaching of Stylophora pistillata in the Northern Red Sea, Plos One, 9, e84968, doi:10.1371/journal.pone.0084968, 2014.

Palmer, M. R. and Pearson, P. N.: A 23 000-year record of surface water $\mathrm{pH}$ and $p \mathrm{CO}_{2}$ in the western equatorial Pacific Ocean, Science, 300, 480-482, 2003.

Palmer, M. R., Brummer, G. J., Cooper, M. J., Elderfield, H., Greaves, M. J., Reichart, G. J., Schouten, S., and Yu, J. M.: Multiproxy reconstruction of surface water $p \mathrm{CO}_{2}$ in the northern Arabian Sea since 29 ka, Earth Planet. Sci. Lett., 295, 49-57, 2010.

Pelejero, C., Calvo, E., McCulloch, M. T., Marshall, J. F., Gagan, M. K., Lough, J. M., and Opdyke, B. N.: Preindustrial to modern interdecadal variability in coral reef $\mathrm{pH}$, Science, 309, 2204-2207, 2005.

Petit, J. R., Jouzel, J., Raynaud, D., Barkov, N. I., Barnola, J. M., Basile, I., Bender, M., Chappellaz, J., Davis, M., Delaygue, G., Delmotte, M., Kotlyakov, V. M., Legrand, M., Lipenkov, V. Y., Lorius, C., Pepin, L., Ritz, C., Saltzman, E., and Stievenard, M.: Climate and atmospheric history of the past 420000 years from the Vostok ice core, Antarctica, Nature, 399, 429-436, 1999.

Pierrot, D. E. L. and Wallace, D. W. R.: MS Excel Program Developed for $\mathrm{CO}_{2}$ System Calculations. In: Carbon Dioxide Information Analysis Center, Oak Ridge National Laboratory, US Department of Energy, Oak Ridge, Tennessee, 2006.

Reynaud, S., Hemming, N. G., Juillet-Leclerc, A., and Gattuso, J. P.: Effect Of $p \mathrm{CO}_{2}$ and temperature on the boron isotopic composition of the zooxanthellate coral Acropora sp, Coral Reefs, 23, 539-546, 2004.

Robertson, A., Overpeck, J., Rind, D., Mosley-Thompson, E., Zielinski, G., Lean, J., Koch, D., Penner, J., Tegen, I., and Healy, R.: Hypothesized climate forcing time series for the last 500 years, J. Geophys. Res.-Atmos., 106, 14783-14803, 2001.

Sanyal, A., Hemming, N. G., Hanson, G. N., and Broecker, W. S.: Evidence for a higher $\mathrm{pH}$ in the galcial ocean from boron isotopes in Foraminifera, Nature, 373, 234-236, 1995.

Schmidt, M. W., Vautravers, M. J., and Spero, H. J.: Western Caribbean sea surface temperatures during the late Quaternary, Geochem. Geophys. Geosyst., 7, Q02P10, doi:10.1029/2005GC000957, 2006.

Schoepf, V., Levas, S. J., Rodrigues, L. J., McBride, M. O., Aschaffenburg, M. D., Matsui, Y., Warner, M. E., Hughes, A. D., and Grottoli, A. G.: Kinetic and metabolic isotope effects in coral skeletal carbon isotopes: A re-evaluation using experimental coral bleaching as a case study, Geochim. Cosmochim. Acta, 146, 164-178, 2014a.

Schoepf, V., McCulloch, M. T., Warner, M. E., Levas, S. J., Matsui, Y., Aschaffenburg, M. D., and Grottoli, A. G.: Short-Term Coral Bleaching Is Not Recorded by Skeletal Boron Isotopes, Plos One, 9, e112011, doi:10.1371/journal.pone.0112011, 2014b.

Shinjo, R., Asami, R., Huang, K.-F., You, C.-F., and Iryu, Y.: Ocean acidification trend in the tropical North Pacific since the mid20th century reconstructed from a coral archive, Mar. Geol., 342, 58-64, 2013.

Smith, T. M., Reynolds, R. W., Peterson, T. C., and Lawrimore, J.: Improvements to NOAA's Historical Merged Land-Ocean Sur- face Temperature Analysis (1880-2006), J. Climate, 21, 2283 2296, 2008.

Steinke, S., Kienast, M., Groeneveld, J., Lin, L.-C., Chen, M.-T., and Rendle-Bühring, R.: Proxy dependence of the temporal pattern of deglacial warming in the tropical South China Sea: toward resolving seasonality, Quaternary Sci. Rev., 27, 688-700, 2008.

Suzuki, A., Gagan, M., Fabricius, K., Isdale, P., Yukino, I., and Kawahata, H.: Skeletal isotope microprofiles of growth perturbations in Porites corals during the 1997-1998 mass bleaching event, Coral Reefs, 22, 357-369, 2003.

Tans, P.: Mauna Loa Observatory Atmospheric $\mathrm{CO}_{2}, \mathrm{NOAA} / \mathrm{ESRL}$ (www.esrl.noaa.gov/gmd/ccgg/trends/), 2012.

Trotter, J., Montagna, P., McCulloch, M., Silenzi, S., Reynaud, S., Mortimer, G., Martin, S., Ferrier-Pagès, C., Gattuso, J.-P., and Rodolfo-Metalpa, R.: Quantifying the $\mathrm{pH}$ "vital effect" in the temperate zooxanthellate coral Cladocora caespitosa: Validation of the boron seawater pH proxy, Earth Planet. Sci. Lett., 303, 163-173, 2011.

Venn, A., Tambutte, E., Holcomb, M., Allemand, D., and Tambutte, S.: Live Tissue Imaging Shows Reef Corals Elevate $\mathrm{pH}$ under Their Calcifying Tissue Relative to Seawater, Plos One, 6, 1-9, 2011.

Venn, A. A., Tambutté, E., Holcomb, M., Laurent, J., Allemand, D., and Tambutté, S.: Impact of seawater acidification on $\mathrm{pH}$ at the tissue-skeleton interface and calcification in reef corals, Proc. Natl. Acad. Sci., 110, 1634-1639, 2013.

Vinther, B. M., Buchardt, S. L., Clausen, H. B., Dahl-Jensen, D., Johnsen, S. J., Fisher, D. A., Koerner, R. M., Raynaud, D., Lipenkov, V., Andersen, K. K., Blunier, T., Rasmussen, S. O., Steffensen, J. P., and Svensson, A. M.: Holocene thinning of the Greenland ice sheet, Nature, 461, 385-388, 2009.

Wade, B., Al-Sabouni, N., Hemleben, C., and Kroon, D.: Symbiont bleaching in fossil planktonic foraminifera, Evolutionary Ecology, 22, 253-265, 2008.

Wang, Y., Huang, C., Sun, B., Quan, C., Wu, J., and Lin, Z.: Paleo$\mathrm{CO}_{2}$ variation trends and the Cretaceous greenhouse climate, Earth-Sci. Rev., 129, 136-147, 2014.

Wei, G., McCulloch, M. T., Mortimer, G., Deng, W., and Xie, L.: Evidence for ocean acidification in the Great Barrier Reef of Australia, Geochim. Cosmochim. Acta, 73, 2332-2346, 2009.

Williams, E. H. and Bunkley-Williams, L.: The world-wide coral bleaching cycle and related sources of coral mortality, Atoll Res. Bull., 335, 1-71, 1990.

Wilson, R., Tudhope, A., Brohan, P., Briffa, K., Osborn, T., and Tett, S.: Two-hundred-fifty years of reconstructed and modeled tropical temperatures, J. Geophys. Res.-Oc., 111, 1-13, 2006.

Yonge, C. M., Nicholls, A., and Yonge, M. J.: Studies on the physiology of corals, British Museum, 1931.

Yu, J., Foster, G. L., Elderfield, H., Broecker, W. S., and Clark, E.: An evaluation of benthic foraminiferal B/Ca and delta B-11 for deep ocean carbonate ion and $\mathrm{pH}$ reconstructions, Earth Planet. Sci. Lett., 293, 114-120, 2010.

Yu, K.-F., Zhao, J. X., Wei, G. J., Cheng, X. R., and Wang, P. $\mathrm{X}$.: Mid-late Holocene monsoon climate retrieved from seasonal $\mathrm{Sr} / \mathrm{Ca}$ and delta O-18 records of Porites lutea corals at Leizhou Peninsula, northern coast of South China Sea, Global Planet. Change, 47, 301-316, 2005.

Yu, K.-F., Zhao, J.-X., Shi, Q., Chen, T.-G., Wang, P.-X., Collerson, K. D., and Liu, T.-S.: U-series dating of dead Porites corals in the 
South China sea: Evidence for episodic coral mortality over the past two centuries, Quaternary Geochronol., 1, 129-141, 2006.
Zeebe, R. E., Sanyal, A., Ortiz, J. D., and Wolf-Gladrow, D. A.: A theoretical study of the kinetics of the boric acid-borate equilibrium in seawater, Mar. Chem., 73, 113-124, 2001. 